\title{
Occurrence of virulent and antibiotic-resistant Shiga toxin-producing Escherichia coli in some food products and human stool in Egypt
}

\author{
Osman Mohamed Hamed ${ }^{1}$, Maha Ahmed Sabry ${ }^{1}$, Nawal A. Hassanain ${ }^{2}$, Eman Hamza ${ }^{1}$, Ahmed G. Hegazi ${ }^{2}$ \\ and Marwa Badawy Salman²
}

\begin{abstract}
1. Department of Zoonoses, Faculty of Veterinary Medicine, Cairo University, Cairo, Egypt; 2. Department of Zoonotic Diseases, Veterinary Research Division, National Research Centre, Giza, Egypt.

Corresponding author: Marwa Badawy Salman, e-mail: vet.marwa_m_s@yahoo.com

Co-authors: OMH: osman.hamed39@yahoo.com, MAS: profdrmahaas@yahoo.com, NAH: nawalhassanain@yahoo.com, EH: e.hamza@gmx.ch, AGH: ahmedhegazi128@gmail.com

Received: 14-07-2017, Accepted: 15-09-2017, Published online: 15-10-2017
\end{abstract}

doi: 10.14202/vetworld.2017.1233-1240 How to cite this article: Hamed OM, Sabry MA, Hassanain NA, Hamza E, Hegazi AG, Salman MB (2017) Occurrence of virulent and antibiotic-resistant Shiga toxin-producing Escherichia coli in some food products and human stool in Egypt, Veterinary World, 10(10): 1233-1240.

\begin{abstract}
Aim: Shiga toxin-producing Escherichia coli (STEC) represent a severe public health issue worldwide, causing lifethreatening diseases in the human gastrointestinal tract. This study aimed to determine the occurrence of virulent and antibiotic-resistant STEC in retail meat and milk products and human stool samples and to characterize the genes encoding for virulence and antibiotic resistance among the identified STEC isolates.

Materials and Methods: A total of 260 food samples were randomly collected from retail markets in different localities of El Giza Governorate, Egypt. 50 stool specimens were obtained from children that had diarrhea at Embaba Fever Hospital. All collected samples were initially subjected to bacteriological examination and serotyping, and then subsequently, the isolates were exposed to polymerase chain reaction application and sequencing for the identification of the virulence-related genes. Finally, the virulent STEC isolates were tested for antibiotic susceptibility.

Results: Serotyping of the 76 biochemically identified isolates showed that 18 were STEC with a predominance of nonO157 (16) while 2 O157:K-serotype was detected only in one food and one human isolate. Molecular identification of the virulence genes illustrated that the minced meat showed the highest prevalence of STEC (8\%) as compared to the other food products. In the humans, the $\mathrm{O} 157$ was the only serotype that expresses the Shiga toxin-associated gene (eaeA). Antibiotic susceptibility test displayed that 13 of the 17 food and human isolates (76.47\%) were resistant to cephalothin (KF30). 9 of the 13 cephalothin-resistant isolates harbor the $\beta$ lactamase $\left(b l a_{T E M}\right)$-resistant gene. All isolates were sensitive to chloramphenicol, ciprofloxacin, amikacin, and gentamicin. DNA sequencing and phylogenetic analysis of the stx2-positive minced meat isolate revealed a high genetic relatedness with beef minced meat from the USA and Australia.

Conclusion: This study showed the predominance of non-O157 among the identified isolates. Minced meat showed the highest prevalence of STEC as compared to the other food products, and this work illustrates the necessity to consider the food products as a potential source of the non-O157 STEC serotypes. DNA sequencing and phylogenetic analysis revealed a high genetic relatedness with beef minced meat from the USA and Australia. This highlights the high probability of worldwide spread of such serotypes, signifying the importance of the one world concept.
\end{abstract}

Keywords: antibiotic resistance bacteria, cheese, DNA sequencing, human stool, meat, polymerase chain reaction, serotyping, shiga toxin-producing Escherichia coli.

\section{Introduction}

Escherichia coli $(E C)$ is normally found as normal flora in the intestinal tract of human and warmblooded animals, but some strains have acquired pathogenic or toxigenic virulence factors that make them virulent for human and animals [1]. On the basis of somatic $(\mathrm{O})$, flagellar $(\mathrm{H})$, and capsular $(\mathrm{K})$ antigens, diarrheagenic EC is divided into six pathotypes: Enteroaggregative, enterohemorrhagic/Shiga toxin-producing E. coli (STEC), enteroinvasive,

Copyright: Hamed, et al. Open Access. This article is distributed under the terms of the Creative Commons Attribution 4.0 International License (http://creativecommons.org/licenses/ by/4.0/), which permits unrestricted use, distribution, and reproduction in any medium, provided you give appropriate credit to the original author(s) and the source, provide a link to the Creative Commons license, and indicate if changes were made. The Creative Commons Public Domain Dedication waiver (http:// creativecommons.org/publicdomain/zero/1.0/) applies to the data made available in this article, unless otherwise stated. enteropathogenic, enterotoxigenic, and diffuse adherent $(D A E C)[2]$.

STEC represents a hazardous public health problem worldwide causing various human gastrointestinal tract diseases, including watery or bloody diarrhea, and might develop life-threatening diseases, such as hemorrhagic colitis, thrombotic thrombocytopenic purpura, (TTP) and hemolytic-uremic syndrome (HUS), and the latter is characterized by thrombocytopenia, microangiopathic hemolytic anemia, and acute renal failure [3]. The most important STEC serotypes which have been associated with human illness are O157, O111, O26, O103, O113, O91, O117, O118, O121, O145, O128, and O146 [4]. STEC infections are mainly foodborne infections; foods of high risk for transmission are meat products such as minced meat, sausage, hamburger and luncheon, and dairy products [5]. 
STEC strains are characterized by the production of two powerful phage-encoded cytotoxins causing tissue damage in humans and animals, called Shiga toxins or verotoxins (stxl and stx2) [6]. In addition, a number of accessory virulence factor genes such as the intimin (eae) and the enterohemolysin (hly) have been described [7].

Treatment of EC infection has been increasingly complicated worldwide by the emergence of resistance to most antibiotics. Among these, $\beta$ lactams (e.g. penicillins, cephalosporins, cephamycins, and carbapenems), tetracycline, and aminoglycosides (streptomycin) are of particular interest [8]. The inappropriate use of antibiotics in animal production brought up resistance in commensal and pathogenic bacterial strains. It has been suggested that commensal EC might represent a reservoir of resistance genes for other bacteria [9]. One of the important mechanisms used by antibiotic-resistant EC is enzymes which hydrolyze $\beta$ lactam antibiotics [10] such as extended spectrum $\beta$-lactamases (ESBLs). Many ESBLs are members of TEM (named after the patient temoneira) [11] which are capable to hydrolyze penicillins and first-generation cephalosporins [12].

Resistance to tetracycline is encoded by more than 40 genes (tet-genes), and they are divided into 11 classes, with a majority of classes $(60 \%)$ encoding for membrane-associated efflux proteins. These efflux pumps selectively transport tetracycline from the cytosol to the periplasm, thereby limiting the access of tetracycline to the ribosomes in the cell [13]. Tet $(A)$ is the most common efflux pump type found in commensal and clinical EC animal isolates [14]. The other resistance commonly detected in EC was against streptomycin and is mainly attributed to aadA type gene variants (aadA1, aadA2, and aadA5) [15,16]. Hence, the current study was aimed to determine the prevalence of STEC and to detect virulence genes (stxl, stx2, eaeA, and $h l y A$ ) as well as resistance determinants ( $b l a_{T E M}, a a d A 2$, and Tet $A$ ) among the STEC isolates from examined retail meat and milk products and human fecal samples collected from fever/public hospital in Egypt.

\section{Materials and Methods}

\section{Ethical approval}

Ethical clearance to use human subjects was obtained from the designated health facility (National Research Centre, Giza, Egypt). Written consent was obtained from each person on information of the use of samples. This study was conducted in Giza Governorate, Egypt, at the period from January 2012 to August 2016.

\section{Collection of samples}

A total of 200 meat samples including minced meat $(n=50)$, luncheon $(n=50)$, sausage $(n=50)$, and beef burger $(n=50)$, and 60 Karish cheese samples were collected from retail markets in randomly selected localities in El Giza Governorate. Fecal samples were obtained from 50 hospitalized children with diarrhea at Embaba Fever Hospital.

\section{Bacterial isolation}

This method was performed according to the De Boer and Heuvelink [17]. Briefly, $25 \mathrm{~g}$ from each sample were transferred to tubes containing $225 \mathrm{ml}$ of trypticase soya broth (TSB, Oxoid, England), blended, and incubated at $37^{\circ} \mathrm{C}$ for $24 \mathrm{~h}$ in an incubator (Sheldon MFG Inc., USA). A loopful from each of the previously incubated enrichment broth tubes was streaked over Eosin Methylene Blue agar (EMB, Oxoid, England) and Sorbitol McConkey agar plates (SMAC, Oxoid, England) and then incubated at $37^{\circ} \mathrm{C}$ for $24 \mathrm{~h}$. Suspected colonies were stained with Gram stain and examined microscopically to detect Gramnegative rods. The presumptive colonies were purified on agar slopes and were incubated at $37^{\circ} \mathrm{C}$ for $24 \mathrm{~h}$ for further identification.

\section{Biochemical identification}

Presumptive colonies were confirmed biochemically using GNB 12 A kit (Oxoid, England) for Gramnegative bacilli.

\section{Serotyping}

The identified EC isolates were serotyped by slide agglutination test in the central laboratories of Ministry of Health and Population (Cairo, Egypt) using standard polyvalent and monovalent EC antisera according to Edwards and Ewing [18].

\section{Antibiotic sensitivity test}

Confirmed isolates tested using disk diffusion method on Muller-Hinton agar plates (Oxoid) for susceptibility to commonly used antibiotics (Oxoid, UK), amikacin (AK30, $30 \mathrm{mcg}$ ), amoxicillin/clavulanic acid (AMC30, 20/10 mcg), ampicillin (AMP 10, $10 \mathrm{mcg}$ ), cefotaxime (CTX30, $30 \mathrm{mcg}$ ), ceftriaxone (CR30, $30 \mathrm{mcg}$ ), cephalothin (KF30, $30 \mathrm{mcg}$ ), chloramphenicol (C30, $30 \mathrm{mcg}$ ), ciprofloxacin (CIP5, $5 \mathrm{mcg}$ ), gentamicin (GN10, $10 \mathrm{mcg}$ ), streptomycin (S10, $10 \mathrm{mcg}$ ), and tetracycline (TE30, $30 \mathrm{mcg}$ ). The results were interpreted according to CLSI [19].

\section{Molecular identification of STEC isolates}

\section{DNA extraction}

Genomic DNA was extracted from pure EC colonies using QIAamp DNA Mini kit (Qiagen, Germany) according to the manufacturer's recommendations.

\section{Polymerase chain reaction (PCR) amplification}

Primers for the studied virulence and antibiotic resistance genes (Midland Certified Reagent Company Oligos, USA). The PCR mixture for a total reaction volume of $25 \mu \mathrm{l}$ consisted of $6 \mu \mathrm{l}$ DNA template from each isolate, $12.5 \mu \mathrm{l}$ of Emerald PCR Master Mix (Takara, Japan), $1 \mu \mathrm{l}$ of 20 pmol of each primer, and $4.5 \mu \mathrm{l}$ of PCR grade water. The reactions were performed in T3 thermal cycler (Biometra, Germany) under different conditions for each primer set according to the previous studies as stated in Table-1 [20-26]. 
The PCR products $(15 \mu l$ each) were electrophoresed on $1.5 \%$ agarose gel (Applichem, Germany, $\mathrm{GmbH}$ ). A 100 bp DNA Ladder (Qiagen, Germany) was used to determine the size of the product. The gel was photographed using gel documentation system (Alpha Innotech, Biometra, Germany), and the data were analyzed using computer software.

\section{Sequence analysis}

The amplicons of stx 1 and stx 2 were purified using QIA quick PCR Product extraction kit. (Qiagen Inc., Valencia CA) and then sequenced in Macrogen Company (Korea) using Applied Biosystems 3130 automated DNA Sequencer (USA). The nucleotide sequences were analyzed using BioEdit 7.0.4.1 program. The obtained nucleotide sequences were compared with those available in public domains using NCBI-BLAST server and were deposited in the GenBank Database. Sequence alignments and phylogenetic comparisons of the sequences for the examined genes were performed using MegAlign module of Lasergene DNAStar software.

\section{Results}

- The occurrence of virulent $\beta$-lactam and tetracycline-resistant non-O157 STEC serotypes among meat products and Karish cheese is shown in Table-2, Figures- 1 and 2.

- Antibiotic-resistant non-O157 serotypes were predominant in stools from diarrheic children (Table-3, Figure-2a and b).

- Phylogenetic analysis of stx2-expressing STEC minced meat isolate.

The STEC isolates were sequenced for stx2 gene, and a phylogenetic tree was constructed based on alignment with nine stx2 genes retrieved from NCBI database that showed high homology with our sequence. The phylogenetic analysis demonstrates that the sequence of the minced meat isolates obtained in the present study (KY884001) was clustered with other two beef minced meat $E$. coli isolated from Australia (AF500193) and USA (GQ429166.1), indicating that our isolate might be the source of these two isolates. Interestingly, our isolate shared a

Table-1: Primers used for virulence- and antibiotic resistance-related genes of the STEC isolates.

\begin{tabular}{|c|c|c|c|}
\hline Gene & Primers sequence & Amplified segment (bp) & References \\
\hline stx 1 & $\begin{array}{l}\text { F: ATG TCA GAG GGA TAG ATC CA } \\
\text { R: TAT AGC TAC TGT CAC CAG ACA AT }\end{array}$ & $185 \mathrm{bp}$ & {$[20]$} \\
\hline $\operatorname{st} \times 1^{*}$ & $\begin{array}{l}\text { F: GGTGACTCTAGTAGGTCACA } \\
\text { R: GTATTACCTCCCCCTAAGTC }\end{array}$ & $614 \mathrm{bp}$ & {$[21]$} \\
\hline stx 2 & $\begin{array}{l}\text { F: CCATGACAACGGACAGCAGTT } \\
\text { R: CCTGTCAACTGAGCAGCACTTTG }\end{array}$ & 779 bp & {$[21]$} \\
\hline eae $A$ & $\begin{array}{l}\text { F: ATG CTT AGT GCT GGT TTA GG } \\
\text { R: GCC TTC ATC ATT TCG CTT TC }\end{array}$ & $248 \mathrm{bp}$ & {$[22]$} \\
\hline hlyA & $\begin{array}{l}\text { F: AACAAGGATAAGCACTGTTCTGGCT } \\
\text { R: ACCATATAAGCGGTCATTCCCGTCA }\end{array}$ & $1177 \mathrm{bp}$ & {$[23]$} \\
\hline blaTEM & $\begin{array}{l}\text { F: ATCAGCAATAAACCAGC } \\
\text { R: CCCCGAAGAACGTITC }\end{array}$ & $516 \mathrm{bp}$ & {$[24]$} \\
\hline $\operatorname{aad} A 2$ & $\begin{array}{l}\text { F: TGTTGGTTACTGTGGCCGTA } \\
\text { R: GATCTCGCCTITCACAAAGC }\end{array}$ & $622 \mathrm{bp}$ & {$[25]$} \\
\hline Tet $(A)$ & $\begin{array}{l}\text { F: GGTTCACTCGAACGACGTCA } \\
\text { R: CTGTCCGACAAGTTGCATGA }\end{array}$ & 576 bp & {$[26]$} \\
\hline
\end{tabular}

Primers used for amplification of stx1 gene included in sequencing

Table-2: Prevalence of Shiga toxins and intimin among 0157 and non-O157 serotypes in food products and their antibiotic resistance profiles.

\begin{tabular}{|c|c|c|c|c|c|c|c|}
\hline \multirow[t]{2}{*}{ Type of samples (total no.) } & \multirow[t]{2}{*}{ Serotypes } & \multicolumn{3}{|c|}{ Virulence genes } & \multirow[t]{2}{*}{ Antibiotic resistance profile } & \multicolumn{2}{|c|}{ Resistance genes } \\
\hline & & stx 1 & stx 2 & eaeA & & blaTEM & tetA \\
\hline \multirow[t]{4}{*}{ Minced meat (50) } & O125:K70 & - & - & - & KF30 & - & nt \\
\hline & O125:K70 & + & - & - & KF30 & + & nt \\
\hline & $\mathrm{O} 26: \mathrm{K} 60$ & + & - & + & KF30 & - & nt \\
\hline & $0103: \mathrm{K}-$ & - & + & - & KF30, TE30, AMP10 & + & - \\
\hline \multirow[t]{2}{*}{ Luncheon-50 } & $\mathrm{O} 26: \mathrm{K} 60$ & - & - & - & KF30 & + & nt \\
\hline & $0111:$ K58 & - & - & - & Sensitive to all & nt & nt \\
\hline Beef burger (50) & 0125:K70 & - & - & + & CTX30 & nt & nt \\
\hline \multirow[t]{5}{*}{ Sausage-50 } & 0125:K70 & - & - & - & CTX30 & nt & nt \\
\hline & O124:K72 & + & - & - & KF30 & - & nt \\
\hline & $0157: \mathrm{K}-$ & - & - & - & KF30 & + & nt \\
\hline & O111:K58 & - & - & - & KF30, TE30 & + & - \\
\hline & $0145: \mathrm{K}-$ & - & - & - & TE30, AMP10 & nt & + \\
\hline \multirow[t]{2}{*}{ Karish cheese (60) } & $0124: 72$ & - & - & - & CTX30 & nt & nt \\
\hline & $0124: 72$ & + & - & + & KF30 & + & nt \\
\hline
\end{tabular}

nt $=$ Not tested, $+=$ Positive, $-=$ Negative 
Table-3: Occurrence of Shiga toxins and intimin among 0157 and non-O157 serotypes and their antibiotic resistance in diarrheic children stool specimens.

\begin{tabular}{|c|c|c|c|c|c|c|c|}
\hline \multirow[t]{2}{*}{ Total number } & \multirow[t]{2}{*}{ Serotypes } & \multicolumn{3}{|c|}{ Virulence genes } & \multirow[t]{2}{*}{ Antibiotic resistance profile } & \multicolumn{2}{|c|}{$\begin{array}{l}\text { Resistance } \\
\text { genes }\end{array}$} \\
\hline & & eaeA & stx 2 & stx 1 & & blaTEM & TetA \\
\hline \multirow[t]{3}{*}{50} & O55:K59 & - & - & - & KF30, TE30 & + & + \\
\hline & $\begin{array}{l}\text { O55:K59 } \\
\text { O111:K58 }\end{array}$ & $\begin{array}{l}- \\
-\end{array}$ & $\begin{array}{l}- \\
-\end{array}$ & $\begin{array}{l}- \\
-\end{array}$ & $\begin{array}{l}\text { KF30, S10 } \\
\text { KF30 }\end{array}$ & $\begin{array}{l}- \\
+\end{array}$ & $\begin{array}{l}\text { nt } \\
\text { nt }\end{array}$ \\
\hline & 0157:K- & - & - & + & AMC30, CR30, F30, S10 & + & nt \\
\hline
\end{tabular}

$\mathrm{nt}=$ Not tested, $+=$ Positive, $-=$ Negative

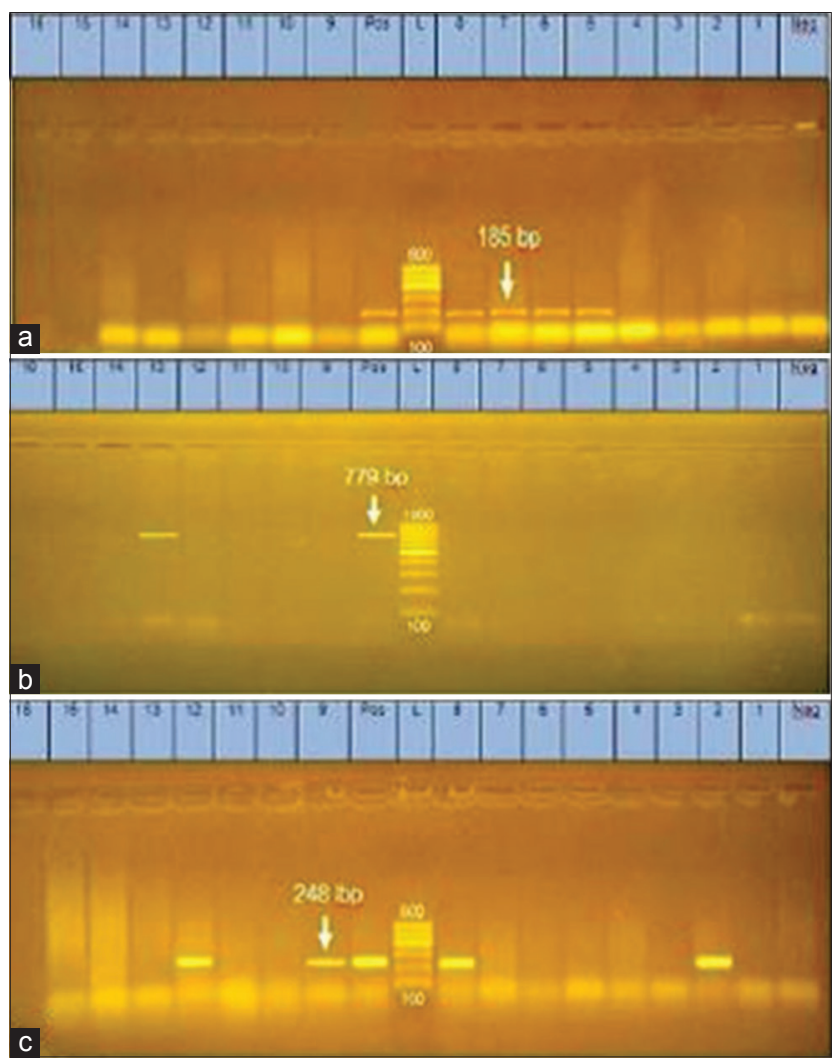

Figure-1: Agarose gel electrophoresis of polymerase chain reaction products amplified for virulence genes: (a) st $x 1$ gene. Lanes (L): DNA ladder (100 bp). Lane (Pos): Positive control. Lane (Neg): Negative control. Lanes 5-8 display positive Shiga toxin-producing Escherichia coli (STEC) isolates that showed specific bands at $185 \mathrm{bp}$. Lanes 1-4 and 9-16 are isolates negative to stx1 gene. (b) Stx2 gene Lane (L): DNA ladder (100 bp). Lane (Pos): Positive control. Lane (Neg): Negative control. Lane 13: Positive STEC isolates showing specific bands at $779 \mathrm{bp}$. Lanes 1-8, 9-12 and 14-16: Negative isolates for stx2 gene. (c) eae $A$ gene. Lane (L): DNA ladder (100 bp). Lane (Pos): Positive control. Lane (Neg): Negative control. Lanes 2, 8, 9, and 12: Positive STEC isolates showing specific bands at 248 bp. Lanes 1 , $3-7,10,11$, and 13-16: Isolates negative to eae $A$ gene.

common ancestor with two isolates from Asia (fish isolate from India, JX206445; yak isolate from China, KP120720.1) and two isolates from Europe (bovine fecal isolate from Switzerland, FM177471.1; human fecal isolate from Germany, FR851896.1) (Figure-3).

\section{Discussion}

STEC is recognized as one of the most important recently emerged group of foodborne pathogens

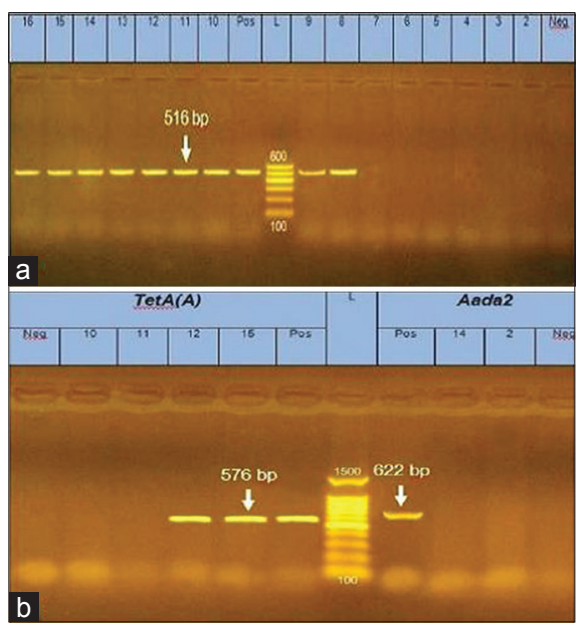

Figure-2: Agarose gel electrophoresis of polymerase chain reaction products for determinants of antibiotic resistance. (a) bla TEM gene in $\beta$-lactams resistant isolates. Lanes (L): DNA ladder (100 bp). Lane (Pos): Positive control. Lane (Neg): Negative control. Lanes 8-16: Positive STEC isolates showing specific bands at (516 bp). Lanes 2-7 isolates negative to bla TEM gene. (b) Tet (A) and Aada2 genes in tetracycline and streptomycin-resistant isolates. Lane (L): DNA ladder (100 bp). Lane 1 (Neg): Negative control for Aada2 gene. Lanes (2 and 14): negative isolates for Aada2 gene. Lane 4 (Pos): Positive control for Aada2 gene. Lane 6 (Pos): Positive control for Tet $(A)$ gene. Lanes (12 and 15): Positive isolates for Tet $(A)$ gene showing specific bands at (576 bp) Lane s (10 and 11): Negative isolates for Tet $(A)$ gene. Lane 11 (Neg): Negative control for Tet $(A)$ gene.

responsible for serious outbreaks worldwide [27,28]. In this study, the overall prevalence of STEC in the examined meat products was 3\% (6 out of 200) which is higher than 0.3 recorded by Loukiadis et al. [29] from France and similar to Hessain et al. [30] in Saudi Arabia. Other studies reported higher prevalence in meat products that range from $9.38 \%$ in Egypt [31] to $11.6 \%$ in Romania [32]. These variations in the prevalence rate of STEC might be explained by the type of samples examined their source as well as a method of detection. In this regard, in this study, the highest percentage of STEC was found in minced meat (8\%, 4 out of 50) as compared to beef burger and sausage that showed the presence of one STEC isolate. In contrast, the luncheon isolates were STEC negative. Raw meat was shown to contain high prevalence of STEC $[33,34]$ which might explain their presence in sausage and beef burger since these products are 


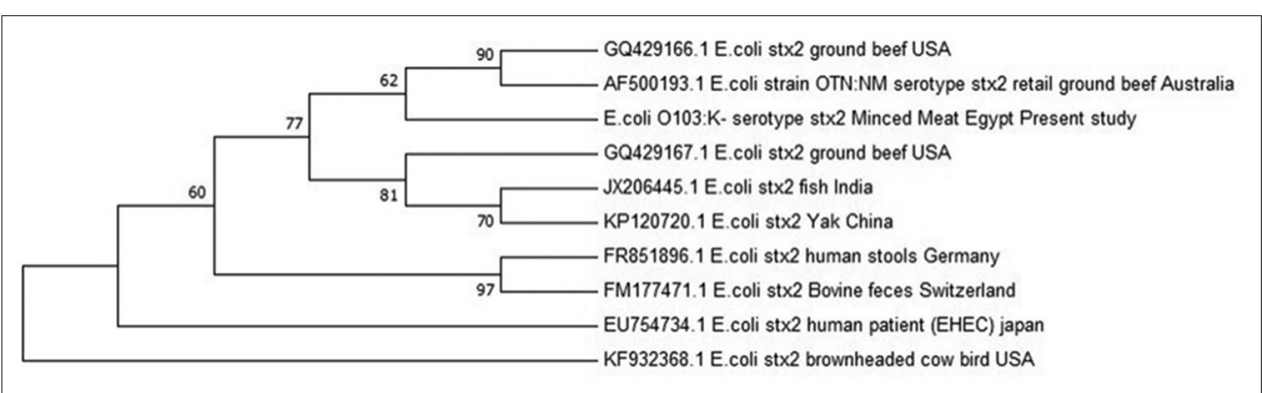

Figure-3: Phylogenetic analysis of Shiga toxin 2-producing Escherichia coli strain isolated from minced meat (KY884001).

prepared from raw meat and not cooked but preserved by lactic acid fermentation.

One of the most popular Egyptian diets is cheese due to its high protein content, low fat, and price [35]. Cheese, especially those made from raw milk like Karish, has been incriminated in recent foodborne outbreaks [36]. Our results showed contamination of Karish cheese samples with STEC in a percentage of $1.7 \%$ ( 1 out of 60$)$ that is similar to other studies performed in Egypt [37].

Like other studies performed in Egypt [31,38], the non-O157 serotypes (O125, O26, O111, O145, and O103) were most commonly present in food products. The O157 serotype was isolated only from sausage but not from the other food products. This finding is similar to other reports $[33,39]$ that demonstrated the inability to isolate the $\mathrm{O} 157$ serotype from minced meat, burger, and luncheon.

Molecular identification of the virulence genes confirmed the previous report [40] that stxl predominates over st 2 in STEC isolates from food products. In this study, the st 1 1, stx2, and eaeA genes were harbored mainly by minced meat STEC isolates. This is consistent with an Indian study performed by Sethulekshmi et al. [34] and in contrast with Dambrosio et al. [41] who stated that none of the meat STEC isolates harbored stx 1 or stx 2 genes. Interestingly, one of the two Karish STEC isolates carried both stxl and eaeA genes. However, the intimin gene (eaeA) acts as an accessory factor that is thought to enhance the virulence of STEC, and some STEC strains not harboring eaeA have been shown to cause human illnesses [42]. None of our STEC isolates carries hlyA gene, and this agrees with Abd El-Tawab et al. [43] and Khatib et al. [44]. This might be due to the presence of iutA gene encoding aerobactin which compensates for the absence of hly $A$ gene [45]. Further study is needed to examine whether our isolates carry iutA gene instead of $h l y A$ because the isolates usually have either iut $A$ or $h l y$, but rarely both genes [45].

The public health importance of EC was examined in diarrheic children. Like in meat products, the non-O157 was the common serotype isolated from the diarrheic children in the present study. Although the $\mathrm{O} 157$ is the most frequent serotype causing human illnesses, there is rising evidence that non-O157 serotypes are linked to human outbreaks [46,47]. Our results provide additional evidence for the possible association of non-O157 serotypes with clinical disease in humans. Furthermore, the human isolates expressed neither stx 1 nor stx 2 genes except for one isolate of the $\mathrm{O} 157$ serotype were found to carry eaeA gene.

Examination of antibiotic susceptibility patterns of the animal and human isolates revealed that 17 of the 18 serotyped STEC isolates exhibited resistance to one or more antibiotic agents, and the majority of them (13 of the 17 [76.47\%]) were resistant to cephalothin (KF30) irrespective to their origin (food or humans). Among the $13 \mathrm{KF} 30$-resistant STEC isolates, nine harbor the blaTEM-resistant genes which explain the resistance to cephalothin as it is a $\beta$-lactam first-generation cephalosporin which gets hydrolyzed by the TEM $\beta$-lactamase [48]. Interestingly, two of the KF30-resistant strains were also tetracycline resistant with one of them carry tetA resistance gene. Resistance to cephalothin and tetracycline in EC strains isolated from different sources is consistent with other studies performed on different type of samples worldwide [49-53]. This highlights the widespread and lengthy use of both antibiotics for the treatment of human diseases and as a growth promoter in animals. Interestingly, all isolates were susceptible to chloramphenicol, ciprofloxacin, amikacin, and gentamicin, signifying the effective use of such antibiotics in the control of infection with STEC in animals and humans. This agrees with the study of Jiao et al. [54] and Jeyasanta et al. [55] who reported that amikacin and ciprofloxacin are among the effective antibiotics used to treat EC infection.

Strikingly, the Aada2 resistance gene was not detected in any of the streptomycin-resistant isolates, suggesting that such resistance might be mediated by other yet undescribed genes [56]. The present results of antibiotic susceptibility agree and disagree with other studies, pointing to the variability in antibiotic resistance pattern according to the type of isolates, time, and development of multiple drug-resistant EC [57].

Phylogenetic analysis of the stx 2 gene from our minced meat STEC isolate showed a high genetic relatedness with $s t x 2$ genes from beef minced meat STEC isolates from Australia and the USA. This might be due to the fact that the minced meat samples 
included in the present study are imported product. Moreover, the current stx 2 gene shared a common origin with those from different types of samples such as Indian fish, Chinese yak, Swiss bovine feces, and German human stools. Our results highlight the possible transmission of E.Ccarrying such gene worldwide through trade.

\section{Conclusion}

In this study, minced meat showed the highest prevalence of STEC as compared to the other food products. Antibiotic susceptibility test displayed that majority of the food, and human isolates $(76.47 \%)$ were resistant to cephalothin. DNA sequencing and phylogenetic analysis of the $s t x 2$-positive minced meat isolate revealed a high genetic relatedness with beef minced meat from the USA and Australia. This highlights the high probability of worldwide spread of such serotypes, signifying the importance of the one world concept.

\section{Significance statements}

This study focused on the public health importance of the meat and meat products (minced meat and sausage) as a source of STEC, especially non-O157:H7 and causing human infections and outbreaks. In this study, all STECs were $100 \%$ susceptible to chloramphenicol, ciprofloxacin, amikacin, and gentamicin, signifying that these antibiotics could be of choice to be used in control of infectious diseases of STEC in human. On the other hand, the presence of antimicrobial-resistant EC may represent a reservoir of resistance genes for other bacteria such as beta-lactamase blaTEM, TetA, and aadA2 and therefore decrease the efficacy of treatment of other bacterial infections. DNA sequencing and phylogenetic analysis of stx2 gene from our minced meat STEC isolate with available sequences in NCBI revealed that these genes are closely related to that isolated from different countries, especially Australia and USA, which increase the role of importation of meat and meat products in the transmission of EC carrying such gene worldwide.

\section{Authors' Contributions}

OMH: Developed the concept and write the manuscript, MAS: Developed the concept and apply PCR assay, NAH: Developed the concept, apply bacteriological examination, and write the manuscript, EH: Developed the concept, share in bacteriological examination and write the manuscript, AGH: Developed the concept and share in bacteriological examination, and MBS (Corresponding author): Developed the concept, prepare samples, apply bacteriological examination, and apply PCR assay. All authors read and approved the final manuscript.

\section{Acknowledgments}

The authors did not received any external funding for this study. The authors are thankful to staff of the Department of zoonotic diseases in both Faculty of veterinary medicine, Cairo University and National research Centre, Giza, Egypt, for providing necessary research facilities.

\section{Competing Interest}

The authors declare that they have no competing interests.

\section{References}

1. Malik, K. and Memona, H. (2010) Molecular and immunological studies of pathogenic Escherichia coli in meat samples collected from different localities of Lahore. Int. J. Cell Sci. Mol. B, 1: 218-224.

2. Jafari, A., Alani, M. and Bouzari, S. (2012) Escherichia coli: A brief review of diarrheagenic pathotypes and their role in diarrheal diseases in Iran. Int. J. Manage., 4(3): 102-117.

3. Etcheverria, A.I. and Padola, N.L. (2013) Shiga toxin-producing Escherichia coli factors involved in virulence and cattle colonization. Virulence J., 4: 366-372.

4. Rahal, E.A., Fadlallah, S.M., Nassar, F.J., Kazzi, N. and Matar, G.M. (2015) Approaches to treatment of emerging Shiga toxin-producing Escherichia coli infections highlighting the O104:H4 serotype. Front Cell. Infect. Microbiol., 5: 24 .

5. Magwedere, K., Dang, A., Mills, E.W., Cutter, C.N., Roberts, E.L. and De Broy, C. (2013) Incidence of Shiga toxin-producing Escherichia coli strains in beef, pork, chicken, deer, boar, bison, and rabbit retail meat. J. Vet. Diagn. Invest., 25: 254-258

6. Kawano, K., Ono, H., Iwashita, O., Kurogi, M., Haga, T., Maeda, K. and Goto, Y. (2012) Stx genotype and molecular epidemiological analyses of Shiga toxin-producing Escherichia coli $\mathrm{O} 157$ : $\mathrm{H} 7 / \mathrm{H}$ in human and cattle isolates. Eur. J. Clin. Microbiol. Infect. Dis., 31: 119-127.

7. Slanec, T., Fruth, A., Creuzburg, K. and Schmidt, H. (2009) Molecular analysis of virulence profiles and Shiga toxin genes in food-borne Shiga toxin-producing Escherichia coli. Appl. Environ. Microbiol., 75: 6187-6197.

8. Hammerum, A.M. and Heuer, O.E. (2009), Human health hazards from antimicrobial resistant Escherichia coli of animal origin. Clin. Infect. D, 48: 916-921.

9. Alvarez-Fern-Andez, E., Cancelo, A., Díaz-Vega, C., Capita, R. and Alonso-Calleja, C. (2013) Antimicrobial resistance in E. coli isolates from conventionally and organically reared poultry: A comparison of agar disc diffusion and sensitivity test gram-negative methods. Food Control. 30: $227-234$

10. Bush, K. and Jacoby, G.A. (2010) Updated functional classification of beta-lactamases. Antimicrob. Agents Chemother., 54: 969-976.

11. Sharma, J., Sharma, M. and Ray, P. (2010) Detection of TEM and SHV genes in Escherichia coli and Klebsiella pneumoniae isolates in a tertiary care hospital from Indian. J. Med. Res., 132: 332-336.

12. Chandra, V. and Goswami, P.N. (2014) Detection of TEM and SHV genes in extended spectrum beta lactamase (ESBL) producing E. colI and Klebsiella pneumonia isolated from a tertiary care cancer hospital. Natl. J. Med. Res., 4: 201-204.

13. Tuckman, M., Petersen, P.J., Howe, A.Y., Orlowski, M., Mullen, S., Chan, K., Bradford, P.A. and Jones, C.H. 2007. Occurrence of tetracycline resistance genes among Escherichia coli isolates from the phase 3 clinical trials for tetracyclines. Antimicrob Agents Chemother, 51: 3205-3211.

14. Zhang, T., Wang, C.G., Lv, J.C., Wang, R.S. and Zhong, X.H. (2012) Survey on tetracycline resistance and antibiotic-resistant genotype of avian Escherichia coli in North China. Poult. Sci., 91: 2774-2777. 
15. Slama, K.B., Jouini, A., Sallem, R.B., Somalo, S., Sáenz, Y. and Estepa, V. (2010) Prevalence of broad-spectrum cephalosporin-resistant Escherichia coli isolates in food samples in Tunisia, and characterization of integrons and antimicrobial resistance mechanisms implicated. Int. J. Food Microbiol., 137: 281-286.

16. Zhang, X.Y., Ding, L.J. and Yue, J. (2009) Occurrence and characteristics of class 1 and class 2 integrons in resistant Escherichia coli isolates from animals and farm workers in northeastern China. Microb. Drug Resist., 15: 223-228.

17. de Boer, E. and Heuvelink, A.E. (2000) Methods for the detection and isolation of Shiga toxin producing Escherichia coli. J. Appl. Microbiol., 88: 133-143.

18. Edwards, P.R. and Ewing, W.H. (1972) Identification of Enterobacteriaceae. $3^{\text {rd }}$ ed. Burgess Publ. Co., Minneapolis, Minnesota.

19. Clinical and Laboratory Standards Institute, CLSI. (2014) Performance Standards for Antimicrobial Susceptibility Testing, 24 $4^{\text {th }}$ Informational Supplement, Document M100-S24. CLSI, Wayne, P.A., USA.

20. Bélanger, S.D., Boissinot, M., Ménard, C., Picard, F.J. and Bergeron, M.G. (2002) Rapid detection of Shiga toxin-producing bacteria in feces by multiplex PCR with molecular beacons on the smart cycler. J. Clin. Microbiol., 40: 1436-1440.

21. Dipineto, L., Santaniell, O.A., Fontanella, M., Lagos, K., Fioretti, A. and Menna, L.F. (2006) Presence of Shiga toxin-producing Escherichia coli O157:H7 in living layer hens. Lett. Appl. Microbiol., 43: 293-295.

22. Bisi-Johnson, M.A., Obi, C.L., Vasaikar, S.D., Bab, A.K.A. and Hattori, T. (2011) Molecular basis of virulence in clinical isolates of Escherichia coli and Salmonella species from a tertiary hospital in the Eastern Cape, South Africa. Gut Pathog., 3: 3-9.

23. Piva, I.C., Pereira, A.L., Ferraz, L.R., Silva, R.S.N., Vieira, A.C., Blanco, J.E., Blanco, M., Blanco, J. and Giugliano, L.G. (2003) Virulence markers of enteroaggregative Escherichia coli isolated from children and adults with diarrhea in Brasília, Brazil. J. Microbiol., 41: 1827-1832.

24. Colom, K., Pèrez, J., Alons, O.R., Fernández-Aranguiz, A. and Cisterna, R. (2003) Simple and reliable multiplex PCR assay for detection of bla $\mathrm{tem}_{\text {tem }}$ bla $\mathrm{SHV}_{\mathrm{SHV}}$ and $\mathrm{bla}_{\mathrm{OXA}-1}$ genes in Enterobacteriaceae. FEMS Microbiol. Lett., 223: 147-151.

25. Walker, R.A., Lindsay, E., Woodward, M.J., Ward, L.R. and Threlfall, E.J. (2001) Variation in clonality and antibiotic-resistance genes among multi-resistant Salmonella enterica serotype Typhimurium phage-type U302 (MR U302) from humans, animals, and foods. Microbiol. Res., 7: 13-21.

26. Randall, L.P., Cooles, S.W., Osborn, M.K., Piddock, L.J.V. and Woodward, M.J. (2004) Antibiotic resistance genes, integrons and multiple antibiotic resistance in thirty-five serotypes of Salmonella enterica isolated from humans and animals in the UK. J. Antimicrob. Chemother., 53: 208-216.

27. Kudakwashe, M., Huu, A.D., Edward, W.M., Catherine, N.C., Elisabeth, L.R. and Chitrita, D. (2013) Incidence of Shiga toxin-producing Escherichia coli strains in beef, pork, chicken, deer, boar, bison, and rabbit retail meat. J. Vet. Diagn. Invest., 25: 254-258.

28. Llorente, P., Laura, B., Kinue, I., María, V.R. and Adriana, B. (2014) Characterization of Shiga toxin-producing Escherichia coli isolated from ground beef collected in different socioeconomic strata markets in Buenos Aires, Argentina. Biomed. Res. Int., 2014: 9.

29. Loukiadis, E., Callon, H., Mazuy-Cruchaudet, C., Vallet, V., Bidaud, C., Ferré, F., Giuliani, L., Bouteiller, L., Pihier, N. and Danan, C. (2012) Surveillance des E. coli producers de shigatoxines (STEC) dans les denrées alimentaires en France (2005-2011). Bull Epidemiol Hebd (Paris) 55:3-9.

30. Hessain, A.M., Al-Arfaj, A.A., Zakri, A.M., El-Jakee, J.K., Al-Zogibi, O.G. and Hemeg, H.A. (2015) Molecular characterization of Escherichia coli O157:H7 recovered from meat and meat products relevant to human health in Riyadh,
Saudi Arabia. Saudi J. Biol. Sci., 22: 725-729.

31. Mohammed, M.A.M. (2012) Molecular characterization of diarrheagenic Escherichia coli isolated from meat products sold at Mansoura city, Egypt. Food Control., 25: 159-164.

32. Bardasi, L., Taddei, R., Nocera, L., Ricchi, M. and Merialdi, G. (2015) Shiga-toxin-producing Escherichia coli in meat and vegetable products in Emilia Romagna Region, years 2012-2013. Ital. J. Food Saf., 4: 33-35.

33. Agaogu, S., Yavuz, M., Berktas, M. and Guiducouglu, H. (2000) Detection of E. coli O157:H7 in retail ground Beef, raw ground beef patties and raw meat balls solid in van. Eur. J. Mark., 5(2): 73-75.

34. Sethulekshmi, C., Latha, C. and Sunil, B. (2016) Occurrence of enterohaemorrhagic $E$. coli in raw meat samples in Kerala. Int. J. Adv. Res. Biol. Sci., 3: 220-222.

35. Todaro, A.A. and Omar, O.H. (2013) History, processing and quality enhancement of traditional Egyptian kareish cheese: A review. J. Food Sci. Technol., 1: 1-6.

36. Centers for Disease Control and Prevention, CDC. (2007) Escherichia coli O157:H7 infection associated with drinking raw milk-Washington and Oregon, NovemberDecember 2005. Morb. Mortal. Wkly. Rep., 56: 165-167.

37. Abd El-Atty, N.S. and Meshref, A.M.S. (2007) Prevalence of Salmonella and E. coli O157 in Some Foods, Beni-Suef Veterinary Medical Journal, $5^{\text {th }}$ Scientific Conference. p73-78.

38. Zidan, S.A., Tarabees, R. and Hassanin, Z.H. (2014) Comparison of RIDA®QUICK verotoxin/O157 test, verocytotoxicty assay and PCR in detection of Shiga toxins in cultures of human stool, animal faeces and meat products. Assiut Vet. Med. J., 60: 142

39. Silveira, N.T., Silva, N., Contreras, C., Mitagusku, L., Baccin, M.L., Koono, E. and Beraquet, Y. (1999) Occurrence of Escherichia coli $\mathrm{O} 157: \mathrm{H} 7$ in hamburgers in Brazil. J. Food Prot., 62: 1333-1335.

40. Naidu, K.G., Goud, N.R., Gaddad, S.M. and Shivannavar, C.T. (2011), Detection of Shiga toxin genes (stx1 and stx2) and molecular characterization of Shiga toxigenic isolated from diverse sources in Gulbarga region, India. Pharmacophore, 2: 253-265.

41. Dambrosio, A., Lorusso, V., Quaglia, N.C., Parisi, A., La Salandra, G., Virgilio, S., Mula, G., Lucifora, G., Celano, V. and Normanno, G. (2007) Escherichia coli O26 in minced beef: Prevalence, characterization and antimicrobial resistance pattern. Int. J. Food. Microbiol., 118: 218-222.

42. Elhadidy, M. and Mohammed, M.A. (2012) Shiga toxin-producing Escherichia coli from raw milk cheese in Egypt: Prevalence, molecular characterization and survival to stress conditions. Lett. Appl. Microbiol., 56: 120-127.

43. Abd El-Tawab, A.A., El-Hofy, I.F., Nada, M.S. and Deiab, A.A.R. (2015) Detection of virulence genes of enterohaemorrhagic E. coli isolated from some meat products by polymerase chain reaction. Benha Vet. Med. J., 29: 45-52.

44. Khatib, A., Olama, Z. and Khawaja, G. (2015) Shiga toxin-producing E. coli (STEC) associated with Lebanese fresh produce. Int. J. Curr. Microbiol. Appl. Sci., 4: 481-496.

45. Welinder-Olsson, C. and Kaijser, B. (2005) Review: Enterohemorrhagic Escherichia coli (EHEC). Scand. J. Infect. Dis., 37: 405-416.

46. Bettelheim, K.A. (2007) The non-O157 Shiga-toxigenic (verocytotoxigenic) Escherichia coli; under-rated pathogens. Crit. Rev. Microbiol., 33: 67-87.

47. Smith, J.L., Fratamico, P.M. and Gunther, N.W. (2014) Shigatoxin-producing Escherichia coli. In: Sima, S. and Geoffrey, M.G., editor. Advances in Applied Microbiology. Academic Press, Burlington, US. p14597.

48. Lim, K., Yasin, R., Yeo, C., Puthucheary, S. and Thong, K. (2009) Characterization of multi-drug resistant ESBLproducing Escherichia coli isolates from hospitals in Malaysia. J. Biomed. Biotechnol., 2009: 10.

49. Parveen, S., Murphree, R.L., Edmiston, L., Kaspar, C.W., 
Portier, K.M. and Tamplin, M.L. (1997) Association of multiple antibiotic resistance profiles with point and nonpoint sources of Escherichia coli in Apalachicola bay. Appl. Environ. Microbiol., 63: 2607-2612.

50. Schlegelova, J., Babak, V., Klimova, E., Lukasova, J., Navritalova, P., Sustackova, A., Sediva, I. and Rysanek, D. (2002) Prevalence of and resistance to anti-microbial drugs in selected microbial species isolated from bulk milk samples. J. Vet. Med. Educ., 49: 216-225.

51. Schroeder, C.M., Zhao, C., DebRoy, C., Torcolini, J. and Zhao, S., White, D.G., Wagner, D.D., McDermott, P.F., Walker, R.D. and Meng, J. (2002) Antimicrobial resistance Escherichia coli $\mathrm{O} 157$ isolated from humans, cattle, swine, and food. Appl. Environ. Microbiol., 68: 576-581.

52. Adenaike, O., Olonitola, O.S., Ameh, J.B. and Whong, C.M.Z. (2013) Incidence of extended spectrum $\beta$-lactamase producing bacteria and multidrug resistance strains from processed meat 'Suya' sold in a university community. Int. J. Eng. Sci., 2: 12.

53. Colello, R., Etcheverría, A.I., Conza, J.A.D., Gutkind, G.O. and Padola, N.L. (2015) Antibiotic resistance and integrons in Shiga toxin-producing Escherichia coli (STEC). Braz. J. Microbiol., 46: 1-5.

54. Jiao, S.C., Fami, R.M.L., Pedernal, V.A.D. and Cabrera, E.C. (2007) Prevalence of multiple drug-resistant Escherichia coli from chicken, Pig and Nile Tilapia (Oreochromis nilotica) intestines sold in wet markets in Manila and the conjugative transferability of the resistance antimicrobial resistant Escherichia coli from livestock. Philipp. JAS, 90: 64-70.

55. Jeyasanta, K.I., Aiyamperumal, V. and Patterson, J. (2012) Prevalence of antibiotic resistant Escherichia coli in sea foods of tuticorin coast, southeastern India. Adv. Biomed. Res., 6: 70-77.

56. Kehrenberg, C., Boudewijn, C., Haesebrouck, F., de Kruif, A. and Schwarz, S. (2005) Novel spectinomycin/ streptomycin resistance gene, aadA14, from Pasteurella multocida. Antimicrob Agents Chemother., 49: 3046-3049.

57. Sharada, R., Wilfred, R.S. and Thiyageerswaran, M. (2010) Isolation, characterization and antibiotic resistance pattern of Escherichia coli isolated from poultry. Am. Eurasian J. Sci. Res., 5: 18-22. 